ELEMEN ESTETIS KOREOGRAFI TARI CANG-CANG DI KAYUAGUNG KABUPATEN OGAN KOMERING ILIR

Emy Admala Yuliarti

KONSEP KEBERSAMAAN DALAM TRADISI MIDANG MABANG HANDAK PADA MASYRAKAT MORGESIWE KECAMATAN KAYUAGUNG

A. Heryanto

PANGLIMA LAOQT SEBAGAI LOCAL WISDOM MASYARAKAT NELAYAN PESISIR ACEH (STUDI KASUS TENTANG PANGLIMA LAOQT LHOK KECAMATAN SERUWAY KABUPATEN ACEH TAMIANG)

Purnama Sari \& Puspitawati

PENERAPAN MODEL PEMBELAJARAN COURSE REVIEW HORAY TERHADAP KEMAMPUAN MENJELASKAN ALUR CERPEN UNTUK ANAK SDN 52 PALEMBANG Sri Wahyu indrawati

PENGARUH MODEL PEMBELAJARAN ARTIKULASI TERHADAP KEMAMPUAN MENULIS PADA SMP NEGERI 2 PALEMBANG

Yus Vernandes Uzer

PENGARUH MODEL PEMBELAJARAN COMPLETE SENTENCE TERHADAP KEMAMPUAN MENULIS PADA SMP NEGERI 13 PALEMBANG

Yuspar Uzer

$60-70$

PENGARUH MUSIK ANSAMBEL TERHADAP KECERDASAN EMOSI REMAJA

Novdaly Fillamenta \& Mohammad Arfani

PEWAISAN RABAB PIAMAN DI KECAMATAN LUBUK ALUNG

KABUPTEN PADANG PARIAMAN

Irfan Kurniawan

$82-93$

ESTETIKA MOTIF NAGO BESAUNG PADA KAIN SONGKET PALEMBANG Decky Kunian

BENTUK GERAK TARI KAIN DI SANGGAR DEWAN KESENIAN MUSI RAWAS

Pransiska Sepriyanti 


\title{
PANGLIMA LAỌT SEBAGAI LOCAL WISDOM MASYARAKAT NELAYAN PESISIR ACEH (STUDI KASUS TENTANG PANGLIMA LAỌT LHOK KECAMATAN SERUWAY KABUPATEN ACEH TAMIANG)
}

\author{
Oleh: \\ Purnama Sari ${ }^{1}$ \\ Puspitawati ${ }^{2}$
}

(Prodi Pendidikan Antropologi Fakultas IImu Sosial, Universitas Negeri Medan)

Abstrak

Penelitian ini bertujuan untuk mengetahui Panglima Laột sebagai kearifan lokal pada masyarakat di pesisir Aceh. Metode yang digunakan dalam penelitian ini adalah metode penelitian kualitatif deskriptif, yang didasarkan pada penelitian lapangan, mengamati subjek dan objek penelitian serta mengikuti kegiatan mereka untuk mendapatkan data yang akurat dan faktual.teknik pengumpulan data adalah observasi , wawancara dan dokumentasi. Teknik analisa data yang digunakan yaitu mengelompokkan hasil data, menginterpretasikan data, menganalisis data, dan membuat kesimpulan. Hasil penelitian menunjukkan Panglima Laột sebagai salah satu dari kearifan lokal pada masyarakat di pesisir Aceh merupakan ketua adat yang menegakkan hukum adat laut yang hidup dalam masyarakat pesisir Aceh di Kecamatan Seruway .

Kata kunci: Panglima Laột; lembaga adat; kearifan lokal; masyarakat nelayan

\section{A. PENDAHULUAN}

Aceh secara geografis terletak di jalur perdagangan Internasional yaitu selat malaka, banyaknya pelayaran dan pelabuhan di pantai Aceh membuat kapal-kapal asing menjadikannya sebagai tempat transaksi ekonomi sekaligus tempat terjadinya pertukaran atau kontak budaya melalui perdagangan atau ekonomi. Aceh berbatasan dengan laut Andaman di sebelah Utara, dengan Selat Malaka di sebelah Timur, di sebelah Selatan dengan Provinsi Sumatera Utara, dan di sebelah Barat dengan Samudera Hindia.
Sarwan dalam Harmonious Family : 2013 menjelaskan bahwa Etnik Aceh adalah salah satu kelompok "asal" di daerah Aceh yang kini merupakan provinsi Nasional Aceh Darussalam. Orang Aceh yang biasa menyebut dirinya dengan istilah Ureueng (orang) Aceh. Menurut hasil sensus penduduk tahun 1990,penduduk Provinsi Nanggroe Aceh Darussalam berjumlah $\quad 3.415 .393$ jiwa,dengan orang Aceh merupakan penduduk mayoritas.

Dalam foklor Indonesia sering terdengar lagu nenek moyang ku seorang pelaut. Dari lagu ini telah tergambarkan bagaiamna nenek moyang 
bangsa Indonesia telah lama memahami kegunaan laut baik sebagai pemenuh kebutuhan, transportasi maupun komunikasi antar bangsa dan di Indonesia juga pernah muncul kerajaan yang tercatat memiliki dasar dan bercirikan kemaritiman seperti kerajaan Sriwijaya dan Majapahit.

Masyarakat pesisir dan nelayan merupakan komponen utama masyarakat maritim Indonesia, didukung dengan kondisi geografis Indonesia yang memiliki wilayah pesisir lebih luas dibandingakan luas wilayah daratan, sehingga seluruh aktifitas masyarakat pesisir dan nelayan sangatlah berpengaruh pada kondisi kawasan pesisir. Banyaknya aktifitas di lingkungan laut akan rentan menimbulkan masalah, masalah ini muncul bersamaan dengan timbulnya kesadaran masyarakat akan pentingnya pemeliharaan lingkungan hidup demi kelangsungan hidup manusia itu sendiri .

Oleh sebab itu menjaga dan mengelola lingkungan alam laut sangatlah penting, namun menjaga dan mengelola lingkungan alam laut bukanlah hal yang mudah, sehingga perlu adanya pihak-pihak yang membantu dan mengawasi setiap aktifitas di lingkungan laut. Wilayah pesisir yang panjang disertai keanekaragaman suku menyebabkan hampir disetiap pesisir Indonesia memiliki adat istiadat yang menarik dan variatif. Adat istiadat masyarakat pesisir yang di dominasi oleh nelayan ini menjadi kearifan lokal ( local wisdom ) dan statusnya sebagai hukum atau aturan yang dilaksanakan di wilayahwilayah pesisir ini sangat penting mengingat dari sisi historisnya yang didapatkan dalam proses yang sangat panjang dan ditransmisikan secara lisan oleh masyarakat. Dibeberapa wilayah di tanah air sudah banyak kearifan lokal yang menjadi contoh dalam mengelola kawasan pesisir yaitu salah satunya Panglima Laột di Aceh, Awig-Awig di Nusa Tenggara Barat, Malombo di Sulawesi Utara, Rampong di Sulawesi Selatan, Sasi di Maluku dan Maluku Utara, dan Pele-karang di Papua.

Panglima Laột yang terdapat di Aceh adalah lembaga adat yang dimiliki masyarakat yang tinggal di pesisir Aceh dengan memiliki peran dan fungsinya dalam mengatur setiap aktifitas masyarakat pesisir Aceh dalam mengelola lingkungan kelautan meliputi juga mengenai penyelenggaraan ritual- 
ritual adat kelautan seperti khanduri laột, memahami musem keuneunong (musim angin laut), pantangan turun melaột, dan lain sebagainya, berikut juga aktifitas keseharian masyarakat nelayan pesisir Aceh seperti dalam meyelesaikan sengketa antar nelayan dan lain-lain.

Panglima Laột adalah salah satu kearifan lokal yang harus dijaga keberadaannya mengingat bahwa panglima Laột telah ada sejak zaman Sultan Iskandar muda sampai dengan zaman kolonial Belanda dan terus dipertahankan sampai saat ini. Sehingga kearifan lokal (local wisdom) disetiap daerah pesisir merupakan khasanah kebudayaan bangsa yang harus dijaga dan dilestarikan karena memiliki peranan penting dalam mengawasi keberlangsungan aktifitas masyarakat pesisir,termasuk juga dalam hal ini Panglima Laột sebagai local wisdom di wilayah Pesisir Aceh.

\section{B. METODE PENELITIAN}

Dalam penelitian penulis menggunakan penelitian kualitatif dan bersifat deskriptif. Pada penelitian ini, peneliti akan melakukan pengamatan (observasi) terlebih dahulu, kemudian dilanjutkan dengan wawancara terhadap subjek dan objek penelitian. Penelitian dilakukan di Kecamatan Seruway Kabupaten Aceh Tamiang. Pemilihan lokasi penelitian ini didasarkan pada hasil observasi pra penelitian, Peneliti menemukan sebuah kearifan lokal di pesisir Aceh yang masih bertahan sampai saat ini . Kearifan lokal tersebut adalah sebuah lembaga adat yang dinamakan Panglima Laột yang bertugas mengawasi hukum adat laut di daerah tersebut.

Subjek atau informan utama dalam penelitian ini adalah Sekretaris Panglima Laột Ihok Kecamatan Seruway Kabupaten Aceh Tamiang. Yang menjadi objek penelitiannya adalah para nelayan dan masyarakat pesisir di Kecamatan Seruway Kabupaten Aceh Tamiang . Teknik atau tahap - tahap pengumpulan data yang digunakan dalam penelitian ini adalah studi pustaka, observasi/ pengamatan langsung, wawancara, dokumentasi . Teknik yang dipergunakan peneliti dalam penelitian ini adalah secara kualitatif. Menurut Bogdan \& Biklen, 1982 dalam Moleong (2014) analisis kualitatif adalah upaya yang dilakukan dengan cara bekerja dengan data, mengorganisasikan data, memilahmilahnya menjadi satuan yang dapat 
diolah, mensintesiskannya , mencari dan menemukan pola, menemukan apa yang penting dan apa yang dipelajari, serta memutuskan apa yang dapat diceritakan kepada orang lain.

\section{HASIL DAN PEMBAHASAN}

Tamiang merupakan salah satu Kabupaten di Provinsi Aceh, Tamiang sendiri adalah sebuah nama yang berdasarkan legenda dan data sejarah berasal dari kata "Te-Miyang" yang berarti tidak kena gatal atau kebal gatal dari miang bambu. Hal tersebut berhubungan dengan cerita sejarah tentang Raja Tamiang yang bernama Pucook Sulooh, ketika masih bayi ditemukan dalam rumpun bambu Betong (istilah Tamiang "bulooh") dan Raja Tan Penoklah yang kemudian mengambil bayi tersebut. Setelah dewasa dinobatkan menjadi Raja Tamiang dengan gelar "Pucook Sulooh Raja TeMiyang", yang artinya seorang raja yang ditemukan di rumpun rebong (bambu), tetapi tidak kena gatal atau kebal gatal. Kabupaten ini merupakan satu-satunya kawasan di Aceh yang dikuasai oleh etnis Melayu (Tamiang). Disamping etnis Melayu, Kabupaten ini juga terdiri dari etnis Aceh, Gayo, Jawa, Karo, dan lain sebagainya.
Wilayah administratif pemerintahan Kabupaten Aceh Tamiang terdiri dari 12 Kecamatan yakni Kecamatan Banda Mulia, Bandar Pusaka, Bendahara, Karang Baru, Kejuruan Muda, Kota Kuala Simpang, Manyak Payed, Rantau, Sekrak, Seruway, Tamiang Hulu, Tenggulun, serta terdiri dari 212 desa, 1 kelurahan, 27 pemukiman dan 701 dusun yang secara keseluruhan mempunyai luas $1.956,72 \mathrm{Km} 2$ atau 195.672 Hektar. Dari keduabelas Kecamatan tersebut, terlihat bahwa Kecamatan Tenggulun merupakan yang paling luas yaitu $295,55 \mathrm{Km} 2$ atau 29.555 Hektar.

Kecamatan Seruway adalah salah satu Kecamatan yang terdapat di Kabupaten Aceh Tamiang Provinsi Aceh .lbukotanya adalah Tangsi Lama. Adapun letak geografis Kecamatan Seruway adalah 04²432,00"0506'57,00" LU 97²31'28,00"$97^{\circ} 39^{\prime} 34,00^{\prime \prime} \quad$ BT. Luas wilayah Kecamatan Seruway adalah 188,49 Km2 . Suhu udara berkisar antara $260-300$ C dan ketinggian : 20 - 900 M Diatas Permukaan Laut .

- Sebelah Utara berbatasan dengan Kecamatan Kecamatan Bendahara dan 
Kecamatan Banda Mulia

- Sebelah Timur berbatasan dengan Selat Malaka

- Sebelah Selatan berbatasan dengan Provinsi Sumatera Utara

- Sebelah Barat berbatasan dengan Kecamatan Rantau Manusia dalam kehidupan bermasyarakat telah dibekali untuk berlaku dengan menjunjung tinggi nilainilai budaya tertentu. Adapun sesuatu yang telah dijunjung tinggi tersebut belum tentu dianggap penting juga oleh warga masyarakat lain. Sehingga normanorma yang dianggap penting tersebut bergabung dengan norma-norma lainnya dan berubah menjadi suatu pranata atau lembaga sosial untuk mempermudah masyarakatnya dalam menjalani setiap aktifitas di lingkungannya menurut tuntutan ataupun gambaran ideal mengenai cara hidup yang dianut dalam kelompoknya.

Semua lembaga-lembaga sosial mengembangkan kebiasaan-kebiasaan . Ihromi (2000) Kebiasaan (adat) adalah aturan-aturan (sedikit banyak bersifat ketat dan yang sedikit banyak ditunjang oleh "paksaan moral, etis atau malahan paksaan fisik") mengenai cara-cara berperilaku yang harus ditaati oleh warga masyarakat atau kelompok untuk memungkinkan lembaga-lembaga sosial untuk mencapai tujuannnya dan supaya masyarakat dapat dipertahankan .

Untuk dapat membedakan hukum dari aturan-aturan jenis lain, perlu dipahami apa yang dimaksud dengan pranata atau lembaga (institution). Defenisi Malinowsky (dalam Ihromi: 2000) mengenai lembaga adalah sebagai berikut: "Lembaga (pranata) sosial dapat didefenisikan sebagai kelompok orang-orang yang bersatu (dan karena itu terorganisir) untuk tujuan tertentu: yang memiliki sarana kebendaan dan teknis untuk mencapai tujuan tersebut atau paling tidak melakukan usaha yang masuk akal yang diarahkan untuk mencapai tujuan tadi; yang mendukung sistem nilai tertentu, etika, dan kepercayaan-kepercayaan yang memberikan pembenaran kepada tujuan dan yang dalam rangka mencapai tujuan tadi berulang kali melakukan jenisjenis perbuatan yang sedikit banyak dapat diramalkan.

Panglima Laột merupakan suatu lembaga yang mengatur setiap aktifitas dikawasan pesisir Aceh. Adapun fungsi lembaga tersebut demi mencapai tujuan yang sama-sama diinginkan 
masyarakat pesisir, dimana dengan memperhatikan setiap etika, nilai dan kepercayaan-kepercayaan yang berlaku akan menunjang setiap keberhasilan pengelolaan kawasan pesisir .Bagi masyarakat Aceh, istilah Panglima Laột tidak asing lagi di dengar. Panglima Laột adalah lembaga adat yang mengatur atau menguasai wilayah laut Aceh yang memimpin adat-istiadat, tata cara penangkapan ikan dan aktifitas kelautan lainnya, adapun Panglima Laột adalah sebutan sebagai lembaga adat yang menguasai hukum adat laut dan Panglima Laột juga digunakan sebagai sebutan untuk pemimpin lembaga adat ini. Dalam sejarahnya di Indonesia satusatunya daerah yang memiliki Panglima Laột hanyalah Provinsi Aceh yaitu sejak Zaman sultan Iskandar muda.

Muhammad Adli Abdullah, mantan sekretaris Panglima Laột Aceh periode 2005 - 2010 dalam workshop pada tahun 2009 yang diselenggarakan oleh Internatonal Collective Support of Fish Workers (ICSF) dengan tajuk Customary Institutions in Indonesia : do they have a role in Fisheries and Coastal Area Management di Lombok, Nusa Tenggara Barat mengungkapkan bahwa ketika tahun $1292 \mathrm{M}$, Marcopolo, penjelajah dunia sempat singgah di Aceh. Beliau saat itu di sambut oleh Panglima Laột.

Panglima Laột berada di luar struktur organisasi pemerintahan. Tetapi berada langsung dibawah kepala daerah setempat (Gubernur, Bupati, Camat, dan Kepala Desa/geuchik) dan dibantu dengan dinas kelautan dan perikanan adapun batas kekuasaannya dinamakan Ihok jika pada tingkat Ihok. Seperti yang dijelaskan informan yaitu oleh bapak Jafaruddin selaku sekretaris Panglima Laột Ihok Seruway:

"Lhok adalah kuala atau teluk yang biasanya itu adalah batasan wilayah sebagai tempat nelayan menambatkan perahunya, tempat nelayan menjual hasil tangkapannya. Panglima Laột Ihok Kabupaten Aceh Tamiang itu ada Panglima Laột Ihok Manyak payed, Bendahara, Seruway dan Banda mulia dan untuk thok Seruway ada 13 Desa yang masuk kedalam kategori pesisir atau bisa disebut desa nelayan dan kira-kira ada 1428 orang nelayan yang ada di Aceh Tamiang ".

Panglima Laột biasanya seorang yang memiliki sikap bijaksana serta memiliki keahlian dan pengalaman yang lebih dari nelayan lain dalam bidang kelautan sehingga menjadi tokoh 
panutan dan disegani oleh masyakat nelayan. Dan dengan memiliki keahlian khusus dapat sangat membantu masyarakat nelayan agar berhasil saat pulang melaut sebab Panglima Laột mengerti waktu yang baik untuk melaut dan Panglima Laột dapat menjadi tempat nelayan berbagi keluh dan kesahnya dalam menjalankan kehidupan sehari-hari. Selain dari pada itu seorang Panglima Laột biasanya tidak lagi pergi melaut, tetapi tetap di darat agar dapat fokus dalam menjalankan tugasnya sebagai Panglima Laột.

Periode kepemimpinan Panglima Laột adalah selama 8 tahun. Panglima Laột dan sekretaris Panglima Laột Ihok Seruway mendapatkan honor juga yaitu dari pemerintah Kabupaten yaitu sebesar Rp.500.000,- / bulan untuk Panglima Laột dan Rp.400.000,-/ bulan untuk sekretaris Panglima Laột. Panglima Laột Ihok merupakan perpanjangan tangan pemerintah kepada masyarakat, Panglima Laột memiliki SK dari pemerintah kabupaten sehingga ada banyak sekali kebutuhan masyarakat nelayan yang harus dipenuhi pemerintah misalnya kebutuhan alat-alat melaut, seperti boat, jaring atau lainnya dikarena harus ada pengawasan yang ketat terkait aktifitas melaut yang harus diperhatikan pemerintah dan Panglima Laột Ihok dimana pemerintah harus memantau berbagai alat tangkap yang dimiliki masyarakat yang akan mereka gunakan untuk menangkap ikan, tentua haruslah merupakan alat tangkap yang ramah lingkungan oleh karena itu harus ada pengawasan dari Panglima Laột Ihok yang menjadi perpanjangan tangan dinas terkait.

Panglima Laột adalah harus menjaga lingkungan laut dari kerusakan ,seperti tidak boleh menggunakan alat tangkap yang tidak ramah lingkungan dan juga Panglima Laột harus menjalankan hukum adat laut di Ihok Seruway ini, inilah yang selalu kami jalankan selama ini, menjalankan tugas agar kehidupan disini semakin membaik dan masyarakat nelayan Seruway hidup dengan sejahtera karena memang banyak yang harus diperhatikan dan diperbaiki dan memang kebanyakan masyarakat yang tinggal disini menggangtungkan hidupnya dengan melaut atau menjadi seorang nelayan untuk bisa menghidupi keluarganya ,menyekolahkan anak-anaknya dan lainlain. Di wilayah perairan laut Provinsi Aceh terdapat sejumlah aturan 
penangkapan ikan dan bagi hasil ikan. Aturan tersebut tetap merupakan hukum adat bagi nelayan yang melakukan penangkapan di daerah itu, seperti ungkapan informan bapak Jafaruddin yaitu sebagai berikut:

"Hukum adat laut yang ada disini itu ada namanya hari-hari yang dilarang untuk mencari ikan kelaut ,mencari kepiting ,udang dan sebagainya yang terdapat dilaut atau dikatakan hari pantang melaôt,itu ada hari waktu kita memuat khanduri laôt,hari jumat,hari Raya Aidil Fitri ,hari Raya Aidil Adha,hari kemerdekaan dan tanggal 26 desember.

Sanksi-sanksi yang diberikan kepada nelayan yang melanggar ketentuan hukum adat laut akan diberikan sanksi diantaranya adalah Perahunya dinaikkan (tidak oleh digunakan untuk melaut), alat tangkap disita, seluruh hasil tangkapan disita, menjamu anak yatim, bayar salah dengan memberi 1 (satu) ekor kambing, dilarang melaut serendah-rendahnya 3 (tiga) hari dan selama-lamanya 7 (tujuh) hari. Ada beberapa yang harus dipatuhi seperti,(1)Jika didalam aktifitas melaut terjadi musibah tenggelam nelayan di laut, seluruh boat mencari mayat tersebut minimal satu hari penuh dan jika ada boat yang mendapat mayat di laut, boat tersebut berkewajiban mengambil dan membawa mayat tersebut ke daratan; (2)Jika terjadi kerusakan pada boat atau alat penangkapan dilaut, nelayan tersebut memberikan sebuah tanda dengan menaikkan bendera sebagai tanda meminta bantuan. Bagi boat yang melihat tanda tersebut harus datang mendekat untuk memberikan bantuan. Mereka memberikan informasi melalui Radio kepada boat yang lain dan kepada Panglima Laột di darat jika Jika terjadi kerusakan boat atau alat penangkapan serta musibah-musibah lainnya di laut.

Ada beberapa larangan yang tidak boleh dilakukan oleh nelayan dalam aktifitas melaut yaitu diantaranya adalah (1) Dalam Aktifitas melaut dilarang menebang pohon-pohon kayu di pesisir pantai laut seperti pohon cemara, ketapang, bakau dan pohon lainnya yang hidup di pantai karena akan menyebabkan ikan pergi menjauh ketengah laut ; (2) Dalam Aktifitas melaut dilarang melakukan pemboman, peracunan, penglistrikan, dan aktifitas lainnya yang dapat merusak lingkungan laut dan biota lainnya; (3) Dalam aktifitas melaut dilarang menangkap ikan atau 
biota laut yang dilinndungi; (4) Konflik adalah hal yang tidak dapat dipisahkan dari kehidupan manusia, dimanapun kapanpun dan siapapun. Apalagi dengan masyarakat nelayan yang berbeda yang pada umumnya berkarakter keras karena memang kehidupannya ditempah untuk keras dan memang terus menghabiskan waktunya di lautan lepas,sehingga karena sifat tersebut akan sangat rentan menimbulkan gesekan atau konflik diantara masyarakat nelayan.

Ada banyak sekali contoh konflik biasanya pada pembagian hasil tangkapan, pengelolaan hasil tangkapan dan lainnya. Konflik yang terjadi biasanya akan diselesaikan oleh Panglima Laôt dan diselesaikan dengan cara musyawarah ataupun dalam masalah-masalah tertentu dapat diberlakukan sidang terhadap yang berkonflik biasanya dilakukan dibalai nelayan yaitu tempat para nelayan berkumpul .

Ada beberapa upacara adat yang terdpat di Kecamatan Seruway, yaitu adat khanduri laôt, ritual tolak bala dan peusijuek (tepung tawar) Boat Baru Turun Melaut. Dalam Teori Religi E.B Taylor berpendapat bahwa, asal mula religi adalah adanya kesadaran manusia akan adanya jiwa. Kesadaran ini disebabkan oleh dua hal: (koentjaraningrat 1980:48). Adanya perbedaan yang tampak pada manusia antara hal-halyang hidup dan yang mati . Manusia sadar bahwa ketika manusia hidup ada sesuatu yang menggerakkan dan kekuatan yang menggerakkan manusia itu disebut dengan jiwa. ia juga menjelaskan mengenai peristiwa mimpi dimana manusia melihat dirinya ditempat lain (bukan ditempat ia sedang tidur). Hal ini menyebabkan manusia membedakan antara jasmani yang berada di tempat tidur dan rohaninya yang di tempattempat lain yang disebut jiwa .

Taylor mengatakan bahwa jiwa yang lepas ke alam disebutnya dengan roh atau makhluk halus. Inilah menyebabkan manusia berkeyakinan kepada roh yang menempati alam . Sehingga manusia memberikan penghormatan berupa upacara do'a, sesajian dan lain-lain. Upacara-upacara yang dilakukan masyarakat di Kecamatan Seruway merupakan sebuah tradisi yang dipercaya akan dapat melindungi mayarakat dari gangguan hal-hal yang bersifat ghaib, masyarakat percaya hal tersebut merupakan proses 
yang sangat sakral dan hal-hal yang berada diluar kuasa mereka yang harus dipatuhi sekaligus dilestarikan agar keseimbangan hidup yang telah ada akan tetap terjaga.

Ritual yang ada pada masyarakat Seruway contohnya Khanduri Laôt, Khanduri Laôt ini dilaksanakan atas dasar ungkapan syukur masyarakat atas rezeky yang telah diberikan yang Maha kuasa kepada mereka. Semua kegiatan dari mulai persiapan memasak dilakukan dipinggir pantai Kuala Berangau. Dalam acara Khanduri laôt ini biasanya dilakukan pemotongan kambing, kambing yang akan dimasak sebelumnya di potong di pantai Kuala Berangau ini juga kepala kambing yang dipotong lalu dipisahkan dengan bagian tubuhnya. Setelah itu daging dikuliti dan dimasak oleh masyarakat di tempat yang sama sebelum acara puncak dimulai kulit kambing yang sudah dipisahkan dari daging kambing tersebut dimasukkan ampas kelapa dan dibentuk seperti layaknya kambing utuh lalu disambungkan dengan bagian kepalanya sehingga semakin sempurna bentuk kambing tersebut seperti utuh kembali ,lalu beberapa orang memabawa kambing tersebut ketengah laut dengan di dampingi oleh orang yang ahli seperti Pawang laôt sampai ketempat yang tidak tampak dari bibir pantai .

Ritual lain adalah Ritual tolak bala merupakan upacara adat yang dilakukan oleh masyarakat nelayan di Kecamatan Seruway, upacara ini telah ada dari zaman dahulu dan masih bertahan sampai saat ini bersama-sama masyarakat mandi dengan air suci yang telah di bacakan do'a dan air dicampur dengan buah kundur. Dengan adanya ritual ini mengembalikan semangat masyarakat seolah memiliki semangat yang baru. Biasanya selama menjalankan aktifitas sehari-hari selama satu tahun tubuh merasa lelah dan butuh penyegaran atau semangat kembali dan dengan dilakukan Ritual Tolak Bala ini dipercaya akan mengembalikan semangat masyarakat dan siap menyambut musim yang baru.

Ritual lainnya adalah Peusejuk, Peusejuk adalah kegiatan adat yang sering dijumpai digunakan hampir pada setiap kegiatan adat. Peusejuk ini dilakukan seagai doa selamat dan menjauhkan dari mara bahaya sekaligus sebagai obat. Dalam keseharian masyarakat hidup dengan adat-istiadat 
yang beda-beda, adat-istiadat yang berbeda-beda tersebut memiliki kekhasannya masing-masing setiap kita tentu diajarkan untuk selalu melestarikan adat-istiadat dan budaya yang melekat pada diri kita masing-masing, adatistiadat dan budaya yang khas dan mampu bertahan secara turun temurun tentulah memiliki nilai tersendiri sehingga ia masih bertahan sampai-saat ini .

Sesuatu yang telah dijunjung tinggi tersebut belum tentu dianggap penting juga oleh warga masyarakat lain. Sehingga norma-norma yang dianggap penting tersebut bergabung dengan norma-norma lainnya dan berubah menjadi suatu pranata atau lembaga sosial untuk mempermudah masyarakatnya dalam menjalani setiap aktifitas dilingkungannya menurut tuntutan ataupun gambaran ideal mengenai cara hidup yang dianut dalam kelompoknya.Semua lembaga-lembaga sosial mengembangkan kebiasaankebiasaan. Ihromi (2000) Kebiasaan (adat) adalah aturan-aturan (sedikit banyak bersifat ketat dan yang sedikit banyak ditunjang oleh "paksaan moral, etis atau malahan paksaan fisik") mengenai cara-cara berperilaku yang harus ditaati oleh warga masyarakat atau kelompok untuk memungkinkan lembaga-lembaga sosial untuk mencapai tujuannnya dan supaya masyarakat dapat dipertahankan.

Untuk dapat membedakan hukum dari aturan-aturan jenis lain, perlu dipahami apa yang dimaksud dengan pranata atau lembaga (institution). Defenisi Malinowsky (dalam Ihromi: 2000) mengenai lembaga adalah sebagai berikut: "Lembaga (pranata) sosial dapat didefenisikan sebagai kelompok orang-orang yang bersatu (dan karena itu terorganisir) untuk tujuan tertentu: yang memiliki sarana kebendaan dan teknis untuk mencapai tujuan tersebut atau paling tidak melakukan usaha yang masuk akal yang diarahkan untuk mencapai tujuan tadi; yang mendukung sistem nilai tertentu, etika dan kepercayaan-kepercayaan yang memberikan pembenaran kepada tujuan dan yang dalam rangka mencapai tujuan tadi berulang kali melakukan jenisjenis perbuatan yang sedikit banyak dapat diramalkan.

Masyarakat di kecamatan Seruway menjunjung tinggi adat-istiadat tersebut terkhusus pada hukum adat laut yang hidup ditengah mereka, sejak dahulu masyarakat selalu percaya akan 
hukum adat laut yang masih bertahan sampai saat ini tidak luput setiap tahun selalu dilangsungkan beberapa upacara adat-upacara adat untuk menjemput keberkahan atau sekedar ungkapan syukur dan masyarakat selalu patuh akan aturan-aturan adat dalam pelaksanaan penangkapan ikan maupun penangkapan biota laut lainnya hal ini masih bertahan dikarenakan adanya pihak yang mengawasi penegakkan hukum adat laut yaitu Panglima Laột .

Panglima Laột merupakan Kearifan lokal yang dimiliki masyarakat dipesisir Aceh. Hobsbown (1983) mendefinisikan kearifan lokal sebagai seperangkat praktik yang biasanya ditentukan oleh aturan-aturan yang diterima secara jelas atau samar-samar maupun suatu ritual atau sifat simbolik, yang ingin menanamkan nilai-nilai dan norma-norma perilaku tertentu melalui pengulangan yang secara otomatis mengimplikasikanadanyakesinambungan dengan masa lalu (dalam Mudana: 2003 dikutip Purna: 2012). Adapun kearifan lokal tersebut dapat bertahan karena terus ditransmisikan dari generasi ke generasi. (Malinowski dalam Ihromi, 1999) telah mengajukan sebuah orientasi teori yang dinamakan fungsionalisme, munculnya teori tersebut berdasarkan anggapan atau asumsinya, bahwa semua unsur kebudayaan bermanfaat bagi masyarakat di mana unsur itu terdapat dengan kata lain pandangan fungsionalisme terhadap kebudayaan mempertahankan setiap pola kelakuan yang sudah menjadi kebiasaan setiap kepercayaan dan sikap yang merupakan bagian dari kebudayaan dalam suatu masyarakat, memenuhi beberapa fungsi mendasar dalam kebudayaan yang bersangkutan . Panglima Laột sampai saat ini bertahan karena memiliki fungsi yang sangat penting ditengah-tengah masyarakat pesisir Aceh.

Dalam aktifitas keseharian Interaksi antara manusia dan lingkungan akan menghasilkan dampak positif dan dampak negatif Teori Ekosentrisme menawarkan pemahaman yang semakin memadai tentang lingkungan. Kepedulian moral diperluas sehingga mencakup komunitas ekologis seluruhnya, baik yang hidup maupun tidak manusia dengan kesadaran penuh diminta untuk membangun suatu kearifan budi dan kehendak untuk hidup dalam keter kaitan dan saling ketergantungan satu sama lain dengan seluruh isi alam semesta sebagai suatu gaya hidup yang 
semakin selaras dengan alam.Terkait dengan teori etika ekosentrisme ini, Panglima Laột sebagai kearifan lokal masyarakat di pesisir Aceh haruslah terus dipertahankan mengingat perannya dalam mengelola lingkungan alam laut, sehingga tercipta interaksi yang berdampak positif antara manusia dan lingkungannya dengan saling menjaga dan terus memperhatikan etika lingkungan yang hidup ditengah masyarakat tersebut maka akan tercipta kawasan pesisir yang semakin baik.

Jika dilihat lebih dalam pada dasarnya wujud dari pada hukum adat yang berlaku ditengah-tengah masyarakat nelayan merupakan sebuah desain yang telah dibuat sejak zaman dahulu untuk menjaga lingkungan laut. Mengingat akan banyaknya kerusakan yang akan timbul jika tidak adanya sesuatu yang mengawasi keseimbangan antara alam dan manusia. Manusia menggunakan alam sebagai tempat ia mencari pemenuh kebutuhan hidupnya ,manusia menggantungkan hidupnya dengan alam seperti masyarakat di Kecamatan Seruway yang mencari nafkah di laut untuk memenuhi kebutuhan hidupnya sehari-har.
Sehingga ada beberapa hal yang harus diperhatikan jika akan memanfaatkan alam sebagai sumber pemenuh kebutuhan, kita sebagai manusia haruslah memahami tentang kepentingan seluruh komunitas ekologis. Manusia dengan kesadaran penuh diminta untuk membangun suatu kearifan budi dan kehendak untuk hidup dalam keterkaitan dan saling ketergantungan satu sama lain dengan seluruh isi alam semesta sebagai suatu gaya hidup yang semakin selaras dengan alam. Pemahaman masyarakat tentang Antroposentrisme yang mengatakan bahwa nilai dan prinsip moral hanya berlaku bagi manusia dan bahwa kebutuhan dan kepentingan manusia mempunyai nilai paling tinggi dan paling penting dan memandang manusia sebagai pusat dari sistem alam semesta serta pemahaman ini akan sangat merugikan alam ,sewaktu-waktu alam hanya akan menjadi objek exploitasi yang pada akhirnya dapat merugikan segala pihak termasuk manusia yang menggantungkan hidupnya pada alam tersebut.

Masyarakat di Kecamatan Seruway semakin sadar akan pentingnya menjaga alam dengan selalu patuh akan 
aturan-aturan hukum adat laut yang saat berada dibwah pengelolaan ketua adat wilayah laut yaitu Panglima Laột Ihok Seruway.Dengan keselarasan hukum adat laut dan pengawasan serta kebijakan Panglima Laột yang senantiasa menegakkan hukum adat laut yang selaras dengan paham ekosentrisme sehingga akan mampu menjaga alam dari kerusakan ulah tangan manusia senantiasa menjalankan tugas dan perannya serta tetap menjalankan setiap ritual-ritual menghormati laut yang telah ada sejak zaman Sultan Iskandar Muda dan berhasil dipertahankan hingga saat ini .

Sebagai kearifan lokal masyarakat di pesisir Aceh yang terus dipertahankan mengingat perannya dalam mengelola lingkungan alam laut sehingga tercipta interaksi yang berdampak positif antara manusia dan lingkungannya dengan saling menjaga dan terus memperhatikan etika lingkungan yang hidup ditengah masyarakat tersebut maka akan tercipta kawasan pesisir yang semakin baik.

\section{SIMPULAN}

Panglima Laột termasuk salah satu dari kearifan local yang terdapat di Aceh, panglima laot yang ada di kalangan masyarakat nelayan ini bertugas memimpin persekutuan adat pengelola hukum adat laot Panglima Laột adalah salah satu kearifan lokal yang harus dijaga keberadaannya mengingat bahwa Panglima Laột telah ada sejak zaman Sultan Iskandar muda sampai dengan zaman kolonial Belanda dan terus dipertahankan sampai saat ini.

Dalam menjalankan kehidupan masyarakat nelayan harus mematuhi aturan hukom adat laot adapun hukum adat laut ini terkait aturan -aturan penangkapan biota laut ,hari-hari yang ditetapkan untuk tidak boleh pergi melaut,adat arang hanyut dan hukum adat laut lainnya.hukom ini diberlakukan agar dapat menjaga lingkungan laut. Nelayan dan Panglima Laột bekerja sama untuk menjaga keseimbangan alam bagaimanapun masyarakat menggantungkan hidupnya dari hasil laut.

Terdapat beberapa bentuk ungkapan adat dan makna upacaraupacara adat dalam aktifitas menjaga lingkungan laut seperti penyelenggaraan 
ritual-ritual adat kelautan seperti yang ada sejak dahulu serta akan khanduri laột, pantangan turun semakin tercipta kerukunan dan angka melaột,adat barang hanyut ,adat dalam penyelesaian konflik atau sengketa antar terjadinya konflik dan sengketa antar nelayanpun semakin rendah. Kelestarian nelayan, dan adat-adat lain yang lingkungan laut juga semakin lestari. memiliki fungsi yang penting serta sanksi-sanki yang diterapkan jika terjadi pelanggaran adat .Kemampuan yang dimiliki Panglima Laột dalam mengeola dan menegakkan hukum adat laut di wilayah kekuasaan nya yaitu lhok Seruway haruslah ditingkatkan lagi agar masyarakat semakin sadar untuk terus menjaga dan menegakkan hukum adat Bagi pihak pemerintah, khususnya dinas kelautan dan perikanan lebih memperhatikan kebutuhan sarana dan prasarana pendukung dalam penangkapan ikan dan lainnya, sehingga dapat memudahkan Panglima Laột dalam menjalankan tugas memimpin persekutuan adat pengelola hukum adat laut.

laut dan terus melestarikan adat-istiadat

\section{DAFTAR PUSTAKA}

Satrya,Arif. 2015. Politik Kelautan Dan Perikanan .Jakarta: Yayasan Pustaka Obor Indonesia.

Moleong L. 2014. Metodologi Penelitian Kualitatif . Bandung: Remaja Remaja Rosdakarya.

Nawawi, Hadari H. 2012. Metode Penelitian Bidang Sosial. Yogyakarta: Gajah Mada University Press.

Simanjuntak, Bungaran Antonius. 2013. Harmonius Family. Jakarta: Yayasan Pustaka Obor Indonesia.

Ihromi,T.O.(Ed). 1999. Pokok-Pokok Antropologi Kebudayaan. Jakarta: Yayasan Obor Indonesia.

Purna, Made. 2012. Pesta Topan : Kearifan Lokal Masyarakat Samawa. Yogyakarta: Ombak.

Iskandar, Johan. 2010. Ekologi Manusia Dan Pembangunan Berkelanjutan. Universitas Padjadjaran. 
Koentjaraningrat. 1990. Pengantar Antropologi. Jakarta: Rineka Cipta.

Keraf,A.Sonny. 2002. Etika Lingkungan. Jakarta: Kompas.

Soekanto, Soerjono. 2003. Hukum Adat Indonesia. Jakarta: Raja Grafindo Persada.

Rusdi Sufi Dkk. 2002. Adat Istiadat Masyarakat Aceh. Dinas Kebudayaan Prov. Nanggroe Aceh Darussalam. Banda Aceh.

Kutanegara, Pande Made. 2014. Manusia Lingkungan Dan Sungai: Transformasi Sosial Kehidupan Masyarakat Sempadan Sungai Code . Yogyakarta : Ombak.

Wiranata, Gede A. B. 2011. Antropologi Budaya. Jakarta : Citra Aditya.

Satyananda, Made. 2013. Kearifan Lokal Suku Helong Di Pulau Semau Kabupaten Kupang Nusa Tenggara Timur. Yogyakarta : Ombak.

Djuned, T. 1995. Pengelolaan Lingkungan Laut Oleh Panglima Laot (Suatu Studi Dikotamadya Banda Aceh), Laporan Penelitian. Universitas Syiah Kuala, DarussalamBanda Aceh.

Kurniawan, Andri. Faktor-Faktor Yang Mempengaruhi Efektifitas Panglima Laột Dalam Pengelolaan Sumberdaya Alam Laut Dikota Sabang.Jurnal Dinamika Hukum,Vol.8 No.3 September 2008).

Ihromi,T.O. 2000. Antropologi Dan Hukum. Jakarta: Yayasan Obor Indonesia.

Soekanto,soerjono. 1990. Sosiologi suatu pengantar. Jakarta : Raja Grafindo persada.

Haviland, william A dan R.G. Soekadijo.1999. Antropologi II(terj). Jakarta : Erlangga.

Koentjaraningrat. 1984. Kebudayaan Jawa. Jakarta, Balai Pustaka.

Sari, Ika Purnama .2006. Kearifan Tradisional Masyarakat Karo Dalam Pengelolaan Hutan (Studi Kasus Di Desa Dolat Rayat Kabupaten Karo) .Tesis .Universitas Negeri Medan.

(Penelitian hidayat: 2013 tentang peningkatan kapasitas kelembagaan nelayan Sumber: Ejournal.Undip.Ac.Id/Index.Php/Cilekha/Article/Download/6876/5635, Diakses Tanggal 15 Februari 2016).

(KabupatenAcehTamiang,sumber:http://repository.usu.ac.id/bitstream/123456789/55961/3/ Chapter\%20Il.pdf,diakses19 agustus 2016).

Loket pelayanan informasi peta(kementrian pekerjaan umum dan perumahan republik Indonesia; http://loketpeta.pu.go.id/peta-kabupaten-aceh-tamiang,diakses pada 15 februari 2016. 
